\title{
Adjusting the Police Occupational Cultural Landscape: \\ The case of An Garda Síochána
}

Corresponding author

Dr. Sarah Charman

Dr Donal Corcoran

Principal Lecturer

An Garda Síochána

Institute of Criminal Justice Studies

Store Street

University of Portsmouth

Dublin 1.

St George's Building

Republic of Ireland

141 High St

donal.p.corcoran@garda.ie

Portsmouth

PO1 2QQ

sarah.charman@port.ac.uk

KEYWORDS: police culture; An Garda Síochána; police reform; the Morris Tribunal, Irish policing. 


\section{Adjusting the Police Occupational Cultural Landscape: The case of An Garda Síochána}

KEYWORDS: police culture; An Garda Síochána; police reform; the Morris Tribunal, Irish policing.

\section{ABSTRACT}

A central area of interest yet controversy within policing over many decades has been the extent to which there exists a pernicious and pervasive occupational culture which operates in stark contrast to the aims of a principled police force. This article seeks to analyse the contentious issue of the culture of a police force under the pressure of organisational reform, with particular reference to An Garda Síochána, the Irish National Police Service. It draws upon an analysis of interviews conducted with police officers working across a range of units in one division of the national police service of the Republic of Ireland - an organisation that has not long ago been the subject of an post-scandal suggested internal reform agenda, driven by the Morris Tribunal's investigation of a major policing scandal. It presents an appraisal of officer perceptions relating to the key features of An Garda Síochána's 'adjusted' operational level occupational culture as they may be. These imply that the outcomes embedded in a number of reforms might well have altered the 'expected' cultural expressions of the police, thereby, challenging the suitability of 'conventional' themes of police characteristics and practices in relation to Irish police experience on the ground. It seems Irish police officers share an outlook that views formal rules as self-serving and normative orders designed to regulate their professional conduct. 
Garda culture may be characterised by its relative adoption or adaptation of new approaches, methods and techniques in public service delivery. So too it looks as if conventional values relating to police solidarity and loyalty, may have been 'conditionally' adjusted, in accordance with a changing accountability framework. 


\section{INTRODUCTION ${ }^{1}$}

Back in 1966 when Jerome Skolnick, was conceivably considering a speech to coincide with the publication of his first book, Justice without trial: law enforcement in democratic society, he might have wondered what if any future impact his text would have on an understanding of how others comprehend the social world police officers occupy together, how they see themselves in that world and their role within it. Almost certainly he could not have known the levels of interest that social scientists around the world coming after him would subsequently direct towards police culture. As Loftus (2010, p.1) notes: "Police ethnographies have spanned several decades [now] and continue to be widely debated in contemporary discussions of policing". This concentration on police culture as an area worthy of research has impacted upon our understanding; indeed maybe it is now possible to speak of a general acceptance of a paradigm of 'conventional' police occupational culture defined by specific police characteristics and practices over time and setting. Have we in fact reached the point of saturation in respect of police culture where to utter the mere words, conjures up a cognitive-shorthand of broad understanding describing a core set of characteristics and functions?

According to the fixed usage 'police culture' is conventionally used to describe a range of static themes, the central tenet of which is that police services operating in liberal democracies are stereotypically characterised by a wide gap between the formal rules guiding officer procedure and informal rules guiding actual officer practice. Formal

\footnotetext{
${ }^{1}$ The authors would like to thank the anonymous reviewers for their helpful comments on earlier drafts of this paper.
} 
dimensions of police culture - "the politically correct language of the organisation" (Prenzler, 1997, p.33) - can inter alia be seen to include mission statements, ethical declarations, regulations, codes, directives and prescribed procedures. Such features, are said to stand in stark contrast to the informal or occupational view of police culture, which has been articulated as, "that [perhaps more] complex interrelated set (configuration) of learned, created and borrowed beliefs, ideas, values, norms and symbolic systems which characterise and influence" (MacGreil, 1996, p.33) the governing principles of those engaged in policing. It is this interplay between the rational, functioning formal and interpretive informal aspects of a policing organisation, which is believed to produce the regularly monolithic elements of core police culture.

Accordingly, police culture is time and again thought to include a sense of mission towards crime fighting only and the desire for action and excitement, especially the glorification of violence or danger (Loftus 2012, Reiner 2000, Crank 1998, Skolnick and Fyfe 1993, Graef 1989 and Holdaway 1977). Police culture, it is also said, embraces an 'us versus them' division of the social world with its in-group colleague solidarity and social isolation on the one hand, and racist/sexist deleterious components on the other (Loftus, 2012, McLaughlin 2007, Reiner 2000, Waddington 1999 and Crank 1998). Police officers are believed to be continually suspicious especially towards the public, law and legal procedures, they are conservative in politics and morality, and moreover, time and again are marked by cynicism and pessimism of one sort or another (Loftus 2012, Reiner 2000, Crank 1998, Smith and Gray 1983, Vick 1981 and Reis 1972). The police world view is said to be broadly an uncomplicated and unambiguous one. These cultural traditions are transferred and 
reinforced through on-the-job socialisation and arise as officers adapt to the demands of the police role (Van Maanen and Schein 1977).

Two more components are said to complete our descriptive representation of 'conventional' police culture. The first of which, concerns a widespread recognition within the literature, that over time, operational-level police officers will redefine the policy directives of their supervisors if they do not consider such policies to be in keeping with the realities of their everyday practices (Savage 2007, Chan and Dixon 2007, Reiner 2000 and Chan 1997). Finally, police officers are habitually held to be concerned with the preservation of egoistic group mores and self-protection, the offshoot of which directs a tendency towards their behaviours being perceived by those on the outside, as being hostile, guarded and even arrogant. Police culture, therefore, has regularly been presented as having a malign influence on officer attitudes.

Such is the inexorable prevalence of this conventional view of police culture found by successive researchers over the last thirty-five years or so, one could question whether the desire for unanimity and harmony in decision-making to fit in with classic depictions, has at times and in certain places overridden the realistic appraisals of alternatives. As Sklansky (2007, p.20) has noted, "our cultural understandings of the policing organisation are framed within a story of cognitive burn-in". It may well be the case as Young $(2008$, p.197) has proposed that "paradigms power perceptions" and the presence of 'conventional' perceptions may conceivably lead to the filtering of information based on what one assumes to be relevant or irrelevant. We are as a result left as Loftus $(2010$, p.2) has correctly 
suggested, "with a version of police culture which predates the [many and varied] transformations that have since taken place within police organisations and in newly identified social fields of policing." It would not be true to say that all of the literature in this field follows these conventions (see for example Chan, 1997; Waddington, 1999; Foster, 2003 where the limitations of the conventional literature have been challenged). However, those which do challenge this view remain in the minority.

As there have been many modernising reform agendas and professionalising programmes highlighted in respect of policing organisations worldwide, which routinely predict a mutation or change in 'conventional' occupational culture and the concomitant dilution of many of the specific police characteristics and practices outlined above, there ought then to be a widespread sense within the extant literature that such changes as have been introduced have had a revolutionary influence (Bayley 1998), but it is hard to know what to make of the evidence available to date. While it is true that there are some academics claiming to have evidenced successful cultural change programmes in policing organisations (Sklansky 2006, Zhoa, Ni He and Lovrich 1999, and Chan 1997), there is, in recent times, equal confirmation, that change can simply be ignored, resisted, subverted or co-opted. Thus, conventional themes are seen to remain applicable to contemporary times, signifying predictable accounts of police culture that continue to encourage the status quo (Loftus 2012, Loftus 2010, Conway and Walsh 2011, Conway 2010). 
The residual issue of police cultural identity is then left to question. It is debateable whether the existing paradigm of 'conventional' police occupational culture defined by specific police characteristics and practices is still relevant. The core characteristics of 'conventional' police culture may no longer provide a resolute descriptor of what police organisations may currently look like. Does police occupational culture - as a shared set of artefacts - stand fast or adjust?

\section{The Current Research Study}

This article directly addresses many of the issues recently raised by Peter Manning in this journal concerning Irish policing (2012). Manning, in his account of trust and accountability in An Garda Síochána, argues that whilst the force have been very successful in embracing change presentationally, more tangible change and a headlong acceptance of the problems associated with modernity have not been so apparent. The force, he argues, is not only intrinsically resistant to change but attempts to reform the organisation have made only a "modest impact" (Manning, 2012, p. 347). In particular, that paper addresses the legacy of the origins of the force which are seen to be so intertwined with the birth of the state itself that it is successfully shielded from direct and overt critiques through relying upon its iconic historical status. Whilst not specifically concerned with the question of historical legacy in that sense, this paper does engage with the concern Manning also raises about the relative absence of ethnographic study of An Garda Síochána (Manning, 2012, p. 355) and attempts to move beyond the contention that An Garda Síochána is an organisation which is in essence resilient and resistant to change. 
In an attempt to address these issues, this article draws upon an analysis of semi-structured interviews conducted with a cross-section of Irish police officers, working across a range of operational units in a division of An Garda Síochána, the national police service of the Republic of Ireland. This was supported by the interpretive insights of an insider practitioner researcher who is one of the authors of this paper. Specifically, this article seeks to address Gardaí [police personnel] perceptions of the impact of post reform agendas of change upon working practices and attitudes and to situate those attitudes within conventional explanations of police culture. Drawing on data obtained from the interview transcripts of Gardaí, it highlights their perceptions of the key features of An Garda Síochána's 'adjusted' occupational culture, and compares them with Manning's (2012, p.347) recent depiction of An Garda Síochána as “very resilient and resistant to change". These are analytically assessed and contrasted with reference to the 'conventional' tenets of culture that were formulated above.

Before proceeding to an outline of the design and later findings of this research, it is necessary to provide some background detail about the recent reform agenda which was required of An Garda Síochána following the Morris Tribunal's investigation of a major policing scandal. This is essential in order to better appreciate the context of any subsequent perceptual or cultural change.

\section{THE MORRIS TRIBUNAL AS A CONTEXTUAL DRIVER OF CHANGE}

The Morris Tribunal was created by a resolution passed by the National Parliament and 
Senate of Ireland on the 28th March 2002. Amongst other things it was to deal with a number of public complaints raised by the media. Its hearings, chaired by Justice Morris, began in March of the following year and did not draw to a close until it had produced its final report in October 2008. By then, six reports - some with several volumes - had been published, amounting to over four-thousand pages of complaint, contextualisation, and conclusion on the subject of policing in An Garda Síochána.

The key findings of the Tribunal though incredibly intertwined, varied and far too complex to precisely capture here; nevertheless, reach back to events experienced in the late 1990s. At the time, Gardaí working in County Donegal - in close proximity to the sectarian 'Troubles' then happening on the Irish/Northern Irish border before the 'Good-Friday Agreement' - were caught-up in, amongst many other things: the manufacture and planting of hoax explosives and bomb-making equipment finds; a clearly deficient 'murder' investigation; the mishandling of criminal informants; a campaign of provocation and malice directed against particular persons in County Donegal; the mistreatment of persons in custody; and the 'collective' impediment of those investigating these claims. In the wake of Justice Morris having arrived at his findings, an unavoidable conclusion was realised - that significant reform of Irish policing as a whole was necessary if Garda legitimacy was to be recovered.

While the specific word 'culture' was not mentioned by Morris we argue that, it can be inferred that each of the issues identified within his reports were in fact manifestly linked to 
the occupational culture of An Garda Síochána that existed at that time and the wider need for same to change. Justice Morris also suggested that: "Of the Gardaí serving in Donegal it cannot be said that they are unrepresentative or an aberration from the generality. All of them were trained as Gardaí and served under a uniform structure of administration and discipline that is standardised" (Morris, 2006, 5/ 6.02). This was therefore an issue for Irish policing as a whole.

Faced with this contextual driver for change, Garda management, advantageously perhaps, moved swiftly, for on the $13^{\text {th }}$ April 2005, midway through Morris's inquiry, Deputy Garda Commissioner Fitzgerald, appeared before the Morris Tribunal and pledged his personal commitment on behalf of the Garda organisation to "remedy and resolve as many of the areas of concern identified in evidence and subsequently articulated in the Tribunal Reports" as were within his authority and capacity to achieve (Fitzgerald, March 2008, p. 4). The die was strategically cast on high for an internal Garda reform agenda to commence, external legislation to direct this challenge of change was shortly to follow in the form of The Garda Síochána Act 2005.

\section{THE REFORMS}

Whilst space precludes an analysis of all of the change, amongst the more notable reforms introduced by An Garda Síochána, was a Professional Standards Unit, established to examine, review and promote standards of operational, administrative and management performance at all levels within the organisation. The Tribunal also damningly took issue 
with a number of recruitment issues in An Garda Síochána, specifically: that the system of promoting personnel, in its experience, had too often produced superiors who did not bring to the task the requisite level of enthusiasm, commitment and ability (Morris, 2004, 1/13.122); and the failure to make determined efforts to recruit from religious and ethnic communities was ignoring an increasingly multi-ethnic society that might challenge the existent 'them versus us' mentality which pervaded An Garda Síochána (Morris, 2004, 1/13.122). Consequently, new promotion regulations were introduced, which required that two-thirds of recruitment boards comprise non-Garda personnel. Additionally, the previously prohibitive height and Irish language entry-requirements were removed, thereby opening An Garda Síochána up to the potential of receiving a wider diversity of applicants.

Addressing the broader failings of personal responsibility raised by the Tribunal that certain Gardaí had for whatever reason, or reasons, clearly lost sight of their commitment to the broader community they served, the immediate re-engagement of Irish citizens in policing matters through the establishment and maintenance of Joint Policing Committees was measured as vital. Such committees were to consult, discuss and produce recommendations on policing matters affecting their local authority's administrative area. These were to consider levels of crime and anti-social behaviour, to advise An Garda Síochána on how best to perform its functions, arrange public meetings and establish, as necessary, community stakeholder groups and local policing forums for discussion of such matters.

Additionally, the Garda Síochána National Model of Community Policing was introduced to 
build and sustain positive partnerships with all community stakeholders, the stated function of which was to "renew, reinvigorate and re-structure" collaborative 'partnerships' between An Garda Síochána and community members, in order to find workable solutions that increased safety, security and protection in Irish society. This model was designed to reenergise the community policing culture within An Garda Síochána and enhance the organisational importance and attractiveness of the community policing role amongst Garda staff, so that, a strong 'ethos' of community policing would be inculcated throughout the entirety of An Garda Síochána (An Garda Síochána, National Model of Community Policing, 2009, p.1). The skills associated with these approaches, had the capacity to subordinate the physical qualities of law enforcement and demand effective communication and interpersonal skills (Miller 1999).

The Tribunal had come to the conclusion that An Garda Síochána was not achieving the standards of a disciplined force, in point of fact, it was suggested that amongst other things it was urgently necessary for changes in structure to the ethics and training of Gardaí so as to militate against a recurrence of the extraordinary chronicled events (Morris, 2005, 3/5.05). While work towards producing a Garda Code of Ethics has as yet to be fully implemented, Gardaí are not without guidance concerning this issue [An Garda Síochána, Corporate Strategy Document 2007-2009; European Convention of Human Rights; The Declaration of Professional Standards and Ethical Values 2003; and An Garda Síochána, Crime Investigation Manual, 2009], which state that officers are expected to be honest and truthful and always adhere to the principles of fairness and justice, to promote mutual respect, to continuously be willing to learn and to accept change. 
It was recognised within the Tribunal's inquiries that many of the internal systems within An Garda Síochána had remained unaltered for decades. To address this issue an Independent Inspectorate was established to ensure that the resources of An Garda Síochána are used efficiently and effectively and judged by best standards in comparable police forces. Its functions are to inspect or inquire into any aspect of Garda operation or administration and produce a report to the Minister advising of best practice. It was projected that operational practice in An Garda Síochána would also be altered by introducing the Garda Covert Human Intelligence System (CHIS) to enable the safe handling of criminal informants and remove the dangers of corruption which this field of policing can present.

The Tribunal findings that referred to weaknesses of certain Gardaí to answer for their past actions and/or inactions recommended that a new independent body called the Garda Síochána Ombudsman Commission (GSOC) was established, it would be responsible to externally ensure Garda accountability. The key functions of the GSOC are clear, it is to receive complaints from the public about the behaviours of Gardaí, to use its powers and perform its duties with regard to those complaints, to issue guidelines for informal resolution, offer advice on areas for improvement and set out procedures for investigations. Further, they are to report on their investigations to the Garda Commissioner and the Director of Public Prosecutions, to conduct such other investigations into An Garda Síochána as may be necessary; and to examine the practices, policies and procedures of An Garda Síochána. 
As we have already touched upon above, the notion that culture is not just a variable that An Garda Síochána formally has; it was something that defines how the organisation informally is, raises the possibility that reform and change in Irish policing were not simple matters of cumulative and progressive improvements. This moved the challenge of reform onto rocky ground, where, as Brogden and Shearing (1993) remind us in the context of attempted modifications to the South African Police system, rules and regulations may be implemented but fail to have a real impact on occupational culture. The often cited fly in the ointment of reform is that operational-level police culture has an unambiguous ability sited perhaps in the perceptions and free-willed choices of its members - to subvert adjustment efforts if such members do not consider the modifications necessary. As leadership scholars Kouzes and Posner (2002) have noted, successful cultural change within organisations requires employees to share both the desire and the control over the change process. Operational Gardaí have the power to consider and choose if, and how they will respond to an imposed top-down post-scandal change agenda. While change of An Garda Síochána may be reasoned as necessary, if however it is not informed by actual Garda experience, understanding and judgment of what is the right thing to do, it may not decisively be compelled by it.

This arrival at organisational culture as something that involves a prescribed human cognitional and volitional structure provided a useful working approach to illuminate Garda occupational culture. It required a search amongst our participants for their common shared 
experiences, common shared understandings, common judgments and common decisions. The opposites of what was not shared represented individual choices which diverged from that which was generally shared.

\section{THE STUDY DESIGN}

Semi-structured, in-depth, recorded interviews were deemed essential for provision of rich, varied and valuable narratives concerning Garda perceptions. As Kvale has argued,

"The qualitative research interview is a construction site of knowledge ... interviews are particularly suited for studying people's understanding of the meanings in their lived world, describing their experiences and self understanding, and clarifying and elaborating their own perspective on their lived world" (1996: 2 and 105).

Although critics have questioned whether culture can be fully understood through this research method (Alasuutari, 1995), one of the key features of policing cultures, that of storytelling (Van Hulst, 2013), is given ample opportunity to flourish through the utilisation of the interview method. In addition, one of the authors of this paper is a member of An Garda Síochána and conducted all of the interviews. Whilst there are no guarantees, it was felt that this might enhance the extent to which respondents would state actual opinions and might mitigate the occasional formality of the interview process. Whilst insider research can have its potential difficulties, there is also a unique opportunity to observe attitudes, behaviours and changes therein over a considerable period of time. Insider researchers have an historical and cultural knowledge of the organisation and are indeed a part of that history themselves. It also needs to be acknowledged that insider research "is 
not only valid and useful but also provides important knowledge about what organisations are really like" (Brannick and Coghlan, 2007: 72 [emphasis added]). Moving beyond surface explanations and understandings of participant's working environments was after all, a key aspect of this research.

Fifty participants were randomly chosen using a purposive judgement sample. The population strata of all street-level officers (not above the rank of Sergeant) attached to Dublin's north-central policing division were included to represent the operational-level coalface. As has been noted by others elsewhere, there is a distinction between street level officers and management within policing organisations (Reuss-Ianni, 1983) and therefore the potential for top-down management imposed reform may not always be welcome within the lower ranks. This group were therefore of particular interest.

Interviewees were chosen from outside of the County Donegal. Whilst it is true to say that the terms of reference of Morris were restricted to County Donegal, many of his findings and each of the reform programmes towards change had nationwide application. As the capital city of Ireland, Dublin is at the core of Irish policing and the hub of the organisation. Consequently, every member of the organisation would potentially be affected by the Inquiry. The results would therefore provide evidence of whether Gardaí felt that the findings of Morris and the subsequent reforms were relevant only in the north of the country. Furthermore, it is also possible that the Gardaí serving outside of the Donegal policing division might be all the more likely to resist change because of the shared perception that 'up there it was different;' and that what happened on the border in 'war- 
times' has little bearing on Garda activities and functions elsewhere in the south.

Of the selected sample of operational Gardaí thirty-eight Gardaí (76\%) agreed to participate. There were ten Sergeants and twenty-eight officers of Garda rank. Of the ten female officers that participated (which is broadly representative of the demographic profile of An Garda Síochána); there were seven Gardaí and three Sergeants. Correspondingly, there were twenty-one male Gardaí and seven Sergeants. The mean average of years of service when rounded to the nearest whole number was eleven years. All interviews were recorded, transcribed, coded and then analysed systematically by hand. The numbers in brackets after direct quotations refer to that anonymous code.

\section{THE FINDINGS - IRISH POLICE CULTURE AS IT MAY BE}

As was earlier highlighted the principle of free-will is essential to any analysis of police culture, since it holds implications regarding whether individuals can be held accountable for their actions. This principle also recognised the possibility of our finding differences of outlook within An Garda Síochána. So we perhaps ought to have expected Garda perceptions to vary according to a variety of individual variables such as "personality, generation, or career trajectory, and structured variations according to rank, assignment, and specialization" (Reiner, 2000, p.87). It is on the whole perhaps significant then that this research did not uncover any such divisions in group cohesion or the presence of subgroups - although they are admittedly a subgroup themselves all based in one urban city. 
In An Garda Síochána it may be the case that a significant proportion of operational Gardaí see their world through the same metaphorical lens and also cope with the strains of their occupation in unison, albeit the view from such a lens has, as we are about to uncover, adjusted, and presents many interesting valences in contrast with the features of culture presented by 'conventional' police research.

\section{ACCOUNTABILTY}

Had this research discovered in-group isolation to be a core feature of Garda culture, a possible offshoot of this might have been "co-worker solidarity" (Reiner, 2000, p.91). This could have taken the form of participants reporting mutual reinforcements of behaviour and the exposure of instances where Gardaí closed ranks and said nothing. In turn, Gardaí might have been expected to cover-up misconduct when coming under scrutiny from internal or external sources. This would confirm Manning's (2012: 349) view that much of the reform coming from An Garda Síochána is more concerned with "impression management" or "presentational strategies" rather than meaningful change. Instead, this research clearly found that the vast majority of Gardaí had strongly held views which opposed this notion of a "blue-wall of silence" (Conway, 2010). Some examples illustrate this: "if ratting out another member is what I have to do to keep my job - then $f^{* * *}$ it - so be it. If they've done wrong and I'm asked to account for their actions, everybody understands, under the new Act [The Garda Síochána Act 2005] you have to tell and that's that" (R20). Likewise, a significant number offered agreement to the notion that "there is no shame in grassing-out whoever, if you are forced to account for something that is $f^{* * * * *}$ up" (R2). 
The important qualification not to be overlooked in the above excerpts is that "ratting out another member" (R20) or "grassing [them] out" (R2), is, it seems, culturally acceptable with Gardaí at operational-level, only in circumstances where a member has been "asked to account for their actions" (R20) or "forced to account" (R2). It might be suggested therefore that the Gardaí interviewed for this research have not yet fully grasped the notion that being willing to account for what happens in the work-place remains primarily their personal responsibility. Instead they seem to have devolved this prime function to external agents, i.e. Garda management/GSOC.

It can be argued that loyalty in County Donegal was exacted with a code of honour that required Gardaí, back then, not to turn in other Gardaí. This alleged 'wall of silence' conceivably demanded Garda members' respect for and automatic loyalty towards their peer groups ahead of organisational and/or public loyalty; it may have encouraged those involved in the Morris Inquiry to abide by their perceived code of honour and to heed the understood commitment of friendship and silence, rather than justice. Given such a scenario it is perhaps reasonable to assume that in the past a wall of cultural norms prevented all unwanted inspection of An Garda Síochána. While this may once have proved true of policing in County Donegal and perhaps elsewhere, it seems that, nowadays, "there have been big changes to the boys sticking together" (R6). As one Garda anecdotally explained, regarding the formerly existing cultural norm of 'solidarity' in An Garda Síochána: "when the ship is sinking it's every man for himself. Providing for your family comes first" 
(29). It is worth mentioning, perhaps, that when the researcher raised this likely adjustment to cultural norms directing what we termed 'conditional solidarity' with participants, they were left with little doubt that they attributed such change to "the introduction of the Ombudsman [GSOC]" (R14). As one research participant advanced: "It's each man for himself now" (R19). Another was of the view that:

It is compulsory now that you do account for your actions and for whoever is out with you. If there was a time when everybody by keeping their mouths shut and behaving like the three monkeys kept trouble at the door, then that day is well and truly gone now... The expectation that you will cover for another Guard has disappeared; it's not worth your job (R10).

On the face of things it appears then that GSOC has been perceived as: "the new broom" (R34). The majority of those interviewed spoke of a culture of "always having to account for out of the ordinary behaviour now during investigations" (R32). This research based finding stands in contrast to Manning's (2012, p. 357) statement that: "Police accountability in Ireland, in short, is neither to the people at large, nor to any collection of groups, and never has been so." Further the above findings also seriously call into question the aptness of the pessimistic tone adapted by Walsh (2009a) towards the complaint's procedure and the Ombudsman's office in Ireland.

\section{WHISTLE-BLOWING}

It was important to analyse interviewee perceptions regarding whistle-blowing on a colleague, whether loyalty was perceived to be toward An Garda Síochána or to protect the 
public interest. This is related much more to the other side of the accountability coin. The issue was whether Gardaí would be agreeable to report aberrant behaviours of their colleagues. These issues deal with the really persistent problems of 'silence' and 'not denouncing'. After all, deviant Gardaí can only succeed in wrongdoing if they are enabled to do so by those who are complicit.

Those who offered their views on this aspect of the research were almost unanimous in their responses having been asked if they believed 'whistle blowing' is acceptable practice in An Garda Síochána; the reply most recurrently received was "it depends" (R17). This area of reasoning it seems is dependent relative to: "the seriousness of what's been done" (R25); "the politics in the unit" (R36); if I was going to be given the cold shoulder" (16); "whether or not I perceive there was intent" (R8); "whether or not I feel it is my responsibility or a supervisor's to call him to check" (R11); and "it dependents if they've pissed me off or not with what they've done" (R7), thus amalgamating 'conditional' moral judgements about wrongdoing with emotions and self-regulation.

In turn, this may be interpreted to mean that the question for a potential whistle-blower in An Garda Síochána may be whether the 'conditional' fall-out from their actions would be worth the ramifications that resultant reprisals may bring. It seems that misconduct in An Garda Síochána may still involve a degree of value judgement and a thorough internal appraisal of the significance of the offending act, which in turn raises the potential prospect 
of bad behaviour becoming normalised as a result of increased exposure, if not initially addressed.

\section{CULTURAL CHARACTERISTICS}

It was difficult to detect a reported shared sense of discrimination, narrow-mindedness or intolerance amongst the vast majority of those interviewed towards colleagues from diverse backgrounds. Many considered the positive impact of an increasingly diverse recruitment. Some of the examples of these sentiments can be found here: "all different faces, shapes, sizes, religions, genders and persuasions, were a breath of fresh air and long overdue, given those we're policing" (R8). This "new face of An Garda Síochána" (R3) had done much to enrich the organisation since their arrival: "developing a wider ethnic and cultural appreciation" (R18), "helping to translate foreign languages" (R28), "He filled me in on what goes on with them that helped me understand why they behaved the way they do, when they are being interviewed" (R17) and "...they help to legitimize the Guards as being [representative] of all of the people" (R6), were amongst the most commonly cited ostensible benefits to An Garda Síochána. This has resulted in no longer having "an allCatholic, white, Irish male staff" (R25).

Furthermore, although suspicion, especially towards the public, is conventionally a feature of police occupational culture, a significant proportion of the Gardaí who contributed to this research had a much more positive and interactive attitude towards the relationships between police and public. One quote which is representative of many others displayed an 
awareness of their "obligations to cultivate special relationships with the local community through regular contact and exchange of ideas, and partnerships" (R19). One respondent also commented that their position in society was "a special one" (R31), and another suggested "we only hold our powers and authority in trust for the public, we must always operate with integrity and respect - we act on behalf of the public for their protection and good" (R5).

Likewise, while it is often said that police are cynical of strictures prescribed by law and legal procedures (Loftus 2012, Reiner 2000, Crank 1998, Smith and Gray 1983, Vick 1981 and Reis 1972), the Irish police interviewed were far more inclined to have fewer misgivings than what might once have been customarily expected. One Garda captured this issue philosophically when he said: "we work within a system, come what may, you just have to keep trying your best" (R19). While a caginess towards rules, regulations and procedures was inferred to be a key characteristic of the conventional code of policing referred to earlier, especially in the treatment of suspects where police are often said to employ the 'ways and means act' (Reiner 2000), it is unlikely that such breaches of due process or law would be defended by the Gardaí we interviewed as necessary to do their jobs, given that they nearly all to some extent accepted that: "the limitations and accountability measures [were] placed on us for good reason" (R17).

Though 'conventional' police culture might at one time have been distinguished by its authoritarian conservatism; for the most part the shared values, attitudes and norms 
commonly associated with our Garda cohort's culture, had more to do with reporting: "being tolerant to different views and collective human rights" (R33) and "respecting and promoting a plurality of differing views" (R9). So too, public intolerance and pessimism, are also often presented as being characteristics central to the supposed police culture typecast (Reiner, 2000). Arising from the perceptions uncovered here, however, it would be a difficult task to reconcile such negative qualities with the majority of the cohort's ideas.

Arising from this issue, it may be sensible that An Garda Síochána seizes every opportunity to learn from its members' experiences. In this respect the recent introduction [2010] of the 'Lessons Learned Framework' (LLF) mechanism to assimilate operational Garda-learning and wisdom, in interesting. An Garda Síochána have the opportunity to engage with the LLF to support and stimulate the reflexive generation of new lessons and the adoption of lessons learned throughout the Garda organisation by embedding them in their systems, processes, policies and culture.

One of the conventional characteristics of police culture is that the police world view is said to be broadly an uncomplicated one. The insight that this research provides is that Gardaí directed by the latitude presented by their volition and discretion, are perhaps more sophisticated in selecting courses of action or inaction to be applied in response to the situations they may face. Take for example, the representative vision expressed by a Garda Sergeant when he said:

Guards [Gardai] are good at matching the response to the situation. Our strength is 
that we're good at applying common sense and a sensitive touch [when] required. No matter who or what we deal with; we know when to be human, when to laugh, when to have a quiet word, intervene, sweet-talk, do nothing, or if needed create a permanent record, open a file, and investigate. Experience is a great teacher: it gives you good judgement (R4).

Consequently, it is here interpreted that the values of dynamic variables within the police world view and the forces acting on that system at any given time cannot be described as deterministic. Consider the following extract, which is measured representative of many other Garda views captured by this research and potentially elucidates the previous point being made: "Real policing, policing that actually serves to help the public, requires a deft use of common-sense and reason; it requires ingenuity and guile that goes beyond what is situated in statutes or provided for by legal conventions or the Garda Code..." (R28).

Most of the Gardaí interviewed for this study were confident that their decisions were and had to be largely a matter of individual discretion and that, the existence of discretion may well be a blessing for some. It might also be interpreted that a Garda's human qualities and empathies with the public they serve can also govern conduct towards continuously making the 'right' decision. From this perspective Gardaí may well have shown themselves to be "legal craftsmen" rather than "legal actors" (Skolnick, 1969, p.231).

Where then did that leave the conventional typecasting that the cultural traditions of Gardaí might be expected to be transferred and reinforced through on-the-job socialisation and arise as officers adapt to the demands of the police role (Van Maanen and Schein 1977)? Earlier we outlined that police forces operating in liberal democracies, such as the Republic 
of Ireland, are often widely characterised by an extensive gap between formal rules and informal practice. There is often conflict between "the politically correct language of the organisation" (Prenzler, 1997, p.47) and "the complex interrelated set (configuration) of learned, created and borrowed beliefs, ideas, values, norms and symbolic meaningful systems" (MacGreil, 1996, p.33), which characterise and influence the actual governing principles of those engaged within policing. This was not evident from our research findings.

Instead we find that informal occupational culture in An Garda Síochána may be fundamentally linked to many of the contemporary features of formal goal-directed activity. This standpoint conveys an essential appreciation that contemporary Garda culture contradicts some of the assumptions associated with traditional monolithic patterns and with the deterministic constructions of many of the seminal cultural examinations. Moreover, this research contrasts with Loftus' (2010) more recent research which argued that stereotypical police culture remains steadfast and enduring.

The Gardaí participating in this research reflected upon the changing nature of policing in Ireland and were found to display a sense of mission but one which was not simply limited to 'a crime fighting function', as might have been forecast (Loftus 2012, Reiner 2000, Crank 1998, Skolnick and Fyfe 1993, Graef 1989 and Holdaway 1977). Rather, the shared sentiment of the cohort tended to be expressed in the following terms: "public service to the people of Ireland" (R4); "public commitment" (R9); "keeping the peace" (R29); "supporting 
communities" (R11); and "to legitimately work with the community to assist society" (R21). Indeed the Gardaí interviewed asserted a variety of broadly positive remarks in describing their orientations towards community based alternatives to the traditional crime-fighting model. For most they represent: "the only logical way forward" (R22), for another Garda member (R8) newly introduced community partnership programmes were helpful because:

The days of assuming we know what's best are gone. What the public wants now is ownership - ownership of the task of advising policing and to be fair ownership or at least a say in the difficulties that come with that. They want to be kept informed. They want to know resources aren't being wasted and that they can have confidence in the Guards. The way the Guards have achieved that is to engage them at every chance - work with them rather than against them - that's what keeps the info' flowing. The recent changes from reactive policing to more proactive policing have helped to ease public concerns... everyone is trying their best...

Similarly, the desire for action and excitement, especially the glorification of violence as is conventionally portrayed in much of the literature (Reiner 2000, p.88, and Waddington 1999, p.287), was not revealed amongst our cohort. This was exhibited by an appreciation of the complexity and rigour of police work and the importance of following the policies and procedures governing that work. Some examples illustrate this: "being professional and methodically following everything up is what police work is about" (R4). "Giving youngfellows a clip around the lugs or the straightener isn't accepted no more, 'cause it has too bad an effect on the locals... the CPF [Community Policing Forum] would be straight back 
going bananas" (R21). While this extract in particular may infer the presence of a sense of fear amongst Gardaí regarding the repercussions that they may face for delivering the particular forms of summary justice mentioned, collectively however, the overall findings discovered created the impression that the Gardaí interviewed offered value judgements and norms, which speak of Irish policing operating well beyond macho thrill-seeking. In point of fact, Garda officers readily reflected on the importance of "professionally maintaining a positive rapport with the locals" (R13) and "[receiving] input from those most closely affected by anti-social issues" (R25).

Moreover, an 'Us versus Them' division of the social world with its in-group isolation and solidarity on the one hand, and racist/sexist components on the other (Loftus, 2012, McLaughlin 2007, Reiner 2000, Waddington 1999 and Crank 1998) - was not exhibited. On the contrary those informing this research displayed a more expansive role orientation, explaining that:

"...things have changed - interests are more varied now. Guards don't live in stations with each other anymore. They don't socialise in the same way as they used to. We're all so different from each other now, you identify with your home friends, and those you went to university with or those you Facebook with, probably as much, if not more, than you identify with those you work with" (R28).

For another Garda it was simply the case that: "Ireland has changed and we've [An Garda Síochána] changed with it. Here in this station you're a Guard first and religion, race, whatever, comes next" (R16). 


\section{INTERPRETING AN GARDA SÍOCHÁNA’S ‘ADJUSTED’ CULTURE}

Before commencing an overview which seeks to interpret An Garda Síochána's 'adjusted' occupational culture as it may be, we should first consider the link between Garda perceptions and Garda actions. Broadly speaking, "Talk and action are related in either of two ways: on the one hand, 'police sub-culture' might be conceived ... as attitudinal variables that seek to explain police behaviour [what police officers say they do is useful to predict what they do]. Alternatively, 'police sub-culture' might be conceptualized as a hypothetical construct that lends coherence and continuity to the broad spectrum of police thought and practice" [police officers may often say one thing yet do another] (Waddington, 1999, p.288).

Either way, analysts of police sub-cultures have long-since been aware of this potentially contentious gap between 'talk and action', and its intrinsic implications for drawing conclusions from research (see for example, Waddington, 1999, pp.287-309; Glietman, 1994, pp.420-451; Shiner, 2010, pp.947-950 and Loftus', 2008, pp.756-777, respective divergent attempts to address this issue). Concentrating on a delineation of the relationship between Garda perceptions and Garda actions in this research, it must be recognized at this juncture that perception "describes one's ultimate experience of the world and typically involves the processing of sensory input." (Lindsay \& Norman, 1977, p. 2) This view recognizes that the reforms introduced to a Garda's world to affect their culture were not simply neutral objects which stood before Gardaí for their contemplation. Each reform symbolized or served to recall a particular way of behaving, thus provoking reactions which 
were either favourable or unfavourable towards achieving cultural change. Consequently, this connection between the reported perceptions that Gardaí offered and the subsequent actions they may thereafter take was quite a complex issue for a number of reasons. The not least of these reasons being that perceptions are often pre-reflexive and prebehavioural. As a result, they may have a structural, functional and cultural logic, yet were considered at times contra-rational. It is here recognized therefore that the reporting of perceptions in a research setting such as ours may have been affected by factors such as "... self-presentation, self-perception, and self-justification" (see Weber, 1992, pp. 132-134). Indeed, we recognised as Manning warned that "these strategies and tactics [may have] formed a part organisational front work, or the increasingly elaborate impression management now associated with modern policing" (Manning, 2012, p. 349).

Bearing the above in mind, on the whole the narratives revealed within this article indicate that we were not as might have been expected subject to "Garda presentational rhetoric" (Manning, 2012, p. 358). For there were significant changes as well as limited continuities in what might have been considered the 'conventional' occupational traditions of Irish policing as Gardaí possibly sought to make sense of and react to the realities of reforms. For instance, this research, in contrast with the 'conventional' views relating to police culture, generated an assessment of Garda operational-level occupational culture that contradicted the expectancy of a role orientation defined by a wide gap between formal rules and informal practice. Instead, it may be that Garda occupational culture is thought to include: a shared outlook that views formal rules as self-serving legitimate normative orders designed to guide professional conduct. 
Further, it was established that the shift to re-emphasising community policing and the introduction of policing forums throughout all of An Garda Síochána's divisions, have in some regards at least, served to discard the relevance of a mission towards the glorification of aggressive crime fighting. In its place we find that Garda occupational culture at operational-level may be distinguished by its appreciation of the need for trust based initiatives, which are principally focused on peace keeping and crime prevention goals.

Indeed, it is possible that the aforesaid community policing philosophy may likewise have affected the traditional propensity of Gardaí to create an 'us versus them' divide in their social world directing in-group isolation, in favour of the cultural acceptance of alternative pluralistic relations which seek to progressively develop mutual respect between parties and develop partnership.

It might also hold true that police discrimination and narrow-mindedness, have less residual "cognitive burn-in" (Sklansky, 2007, p.1) within Garda occupational culture than might conventionally have been assumed by Manning (2012 p.347). Instead, it may be reasoned that Garda occupational culture is thought to include: a shared outlook that may perhaps be interpreted, as appreciating the need to recognise the message of social justice, through inclusion, and apprehending the idiom of the cultural experiences and dynamics of the communities they serve. 
Similarly, 'cynicism, isolation and intolerance', which are also often presented within 'conventional' literature as being characteristics central to an alleged policing typecast were not revealed in the narratives provided within this research. As an alternative Garda occupational culture may be seen at the very least as more closely concerned with varying degrees of presentation management that show concern for protecting against human rights violations, improving the treatment of different identity groups and promoting better team work.

The one area, however, where the field of culture may not have changed substantially, where some continuity in what might have been considered the 'conventional' occupational traditions of Irish policing was discovered in interviewee's narratives was concerned with Gardaí sticking together no matter what.

The experiences of Gardaí described in this article suggest that those interviewed still see accountability and whistle-blowing as areas fraught with organisational stressors. Increased accountability delivered through GSOC and the weight put on integrity, has meant that the once reputed 'blue wall of silence' is no longer culturally sustainable - Gardaí reported having too much to lose (their careers, attendant financial security and position in Irish society) for protecting other Gardaí from scrutiny for misconduct. Manning's (2012: 357) position that all attempts have failed to make the Garda more accountable are not supported by the findings of this research. Yet accountability as it was with the Gardaí 
interviewed for this research could not by extension be presumed, rather, it was found to be dependent on the subjectivities of the situation with which the Garda found themselves dealing, what we would term 'conditional accountability'. What was clear, however, in relation to accountability within this research is that Garda occupational culture is very much concerned as ever it might have been with some of the age-old [traditional] practices of self-protection, by not involving one's-self in the business of others. Broadly speaking, whistle-blowing was not culturally validated.

Having delivered an interpretation of what may be some of the key 'adjusted' characteristics of Garda occupational culture; next, we must deal with the widespread recognition within the literature, that over time, operational-level police officers will redefine the policy directives of their supervisors if they do not consider such policies to be in keeping with the realities of their everyday practices (Savage 2007, Chan and Dixon 2007, Reiner 2000 and Chan 1997).

\section{DID THE OPERATIONAL-LEVEL CULTURE OF GARDAÍ HINDER CHANGE?}

The Gardaí interviewed for this research have revealed that they appear to have offered little resistance to the reforms introduced to modify behaviours. Instead they have possibly moved with the times and to some extent at least, perhaps, even accepted the challenge of the gauntlet thrown down by Justice Morris. It would seem then that Garda occupational culture according to this sample, has a far less pervasive, malign and potent influence on individual Garda behaviour than might have been conventionally supposed. Moreover, 
through the assortment of vignettes of Garda culture presented above we may clearly state that Gardaí are not "cultural dopes" (Shearing and Ericson, 1991, p. 500), rather they have demonstrated they are capable of selecting what best suits them from the "cultural tool-kit" (Shearing and Ericson, 1991, p. 500) presented by Garda management. From this perspective, we see Gardaí as active agents in the reform process. They are indeed the 'street-level bureaucrats', the not to be forgotten operatives who played a crucial part in the positive articulation and construction of public policies where they have their greatest impact on the ground (Lipsky, 1980).

What of our final issue that police officers are conventionally held to be habitually concerned with the preservation of egoistic group mores and self-protection, the offshoot of which directs a tendency towards their behaviours being perceived by those on the outside, as being hostile, guarded and even arrogant. Police culture, as a result, has regularly been presented as having a malign influence on officer behaviours (see Dunham, and Alpert, 2004; Crank, 2004; and Smith and Alpert, 2007).

Conceivably there is something about each of the police systems being referred to in the policing literature that generates their reported overtly negative cultures. Or perhaps certain personality types in the countries in question have a tendency to be inadvertently recruited into the police. Either explanation is possible or both may be correct. However, it may also be the case that the interpretive premise upon which many of the authors describing conventional police culture based their arguments - that police officers are 
unconsciously predetermined to behave negatively towards the public because of their informal culture - may now to some extent be unsafe. For within this premise there may be an in-built tendentious presumption to make a connection between what are considered to be unconscious core characteristics that police officers form, and the subsequent discriminatory actions it is alleged many officers will take. That somehow police officers are determined because of their culture to be very much at odds with almost every fundamental ethical principle of public service they take an oath to uphold. Moreover, that they are individually not principled enough, not reflexive enough, or simply incapable of overcoming the conditioning of their culture, societal bias, and environment.

In brief, the criticism that can perhaps be levied at many of the studies of police culture previously cited is that, they potentially under played the abilities of police to professionally respond to what is good or bad according to their individual sense of free-willed integrity. It is here respectfully suggested that this present analysis has been revealing in this regard. Indeed, many of the reforms introduced may be observed as having potentially caused the shared perceptions' of Gardaí to adjust and change with the times, rather than remaining steadfast and recoiling from progress.

In conclusion, we must take the view that this research has served to move beyond the contention offered by Manning (2012, p. 347) that An Garda Síochána is an "organisation very resilient and resistant to change". 


\section{FACTORS AFFECTING CULTURAL ADJUSTMENT IN AN GARDA SÍOCHÁNA}

The reform efforts of An Garda Síochána, in their North Central Division, appear to have been met with degrees of trust, goodwill, and satisfaction; they appear to have elicited no small measure of reported commitment and welcome from Garda members.

The challenge for Garda senior management as they embarked on the path of reform postMorris was to cancel out the Garda cultural resistance that had so clearly manifested itself during the Tribunal of Inquiry. Justice Morris had after all suggested that: "Of the Gardaí serving in Donegal it cannot be said that they were unrepresentative or an aberration from the generality. All of them were trained as Gardaí serving under a uniform structure of administration and discipline that is standardised" (Morris, 2006, 5/6.02). He had also taken the broad view that An Garda Síochána as a whole was losing its character as a disciplined force (Morris, 2004, 1/13.102). Subsequently, if change was to occur Garda management had to win over the hearts and minds of all operational-level Gardaí operating not just in County Donegal but throughout the whole country of Ireland, including those in Dublin.

We are of the view, as the central conclusion of this paper, that cultural change demanded by Justice Morris is evident and that this may have primarily happened because the rationale for the reforms being internally implemented was accepted by most of the Gardaí we interviewed. It seems interviewees may have understood that the reforms introduced were necessary to maintain the faith of public support in light of the discomforting disclosure of corruption. The necessity of the reforms appear to have challenged pride in integrity, ideals and the shared values of operational-level Gardaí with reference to how 
their policing ought to work. This analysis is a further example of the dilemma of the relationship between 'law in books' and 'law in action' (McBarnett, 1981; Reiner, 2000) to the extent that it considers the interaction between formal frameworks and occupational cultures. In this context the formal framework rather than being law (police powers) is the policy framework which emerged out of the reform agenda. This framework has created the organisational space within which police occupational cultures have operated and functioned. In other words, the analysis explores the dynamic between the stated objectives of the reform process and the attitudes and perceptions of operatives.

Excluding the obvious introduction of GSOC as an external independent oversight body to monitor the behaviours of its members, it can be argued that An Garda Síochána's reformers strategically appear to have shied away from the introduction of a rigid approach of rule-tightening and supplementary regulations - which inherently assume that rules will bring Gardaí into line with service requirements. Rather, it seems they favoured encouraging public service through persuasive initiatives that appeal to officer's principles. This approach acknowledges Garda professional discretion, yet seeks to raise human awareness through education and mutual respect, with the emphasis being placed on Gardaí adopting correct attitudes when dealing with members of the public.

The Gardaí interviewed for this research conveyed their willingness to police a multi-cultural polity. Moreover, they broadly welcomed the introduction of community policing strategies, preventative policing and multi-agency working, which seem to have re-emphasised a 
partnership approach. The Gardaí interviewed were more inclined to feel loyalty to protect what was felt to be 'right' and 'just', than to at all times unconditionally protect each other from what they personally understand to be wrong. This is something they had been accused of failing to do in County Donegal in the past, leading one to the unavoidable conclusion that partnership processes may have an authoritative effect on cultural resistance.

Before concluding this appraisal it is important to consider one final issue that may have brought about change in An Garda Síochána. Since the introduction of GSOC to both provide oversight and scrutinize public complaints, it can be observed to have had a significant impact on the cultural norms of Gardaí. This finding stands in contrast to Manning's (2012, p.357) arguments that "efforts to constrain and make accountable the Garda to public complaints or governmental units other than the ministry have been unsuccessful." The essential lesson from this experience seems to be that oversight mechanisms and accountability are part of the solution to corruption and deviance. The introduction of GSOC in the Irish context has it seemed resulted in a commonly shared perception of fear amongst the Gardaí interviewed. On the face of things it appears then that GSOC has been perceived as: "The ravenous and ambitious watch-dog ever baying for a member [Garda] to devour without salt" (R16). The majority of those interviewed spoke of a change in culture, one speaking of "always having to account for out of the ordinary behaviour now during investigations" (R32). 
Thus it seems that GSOC may well have effected a significant adjustment in Garda solidarity from the position of involuntary loyalty and a committed defence of one another, as was prevalent in the Morris Inquiry, to the present condition of 'conditional solidarity' only. As evidenced in the following representative extract: "when the ship is sinking it's every man for himself. Providing for your family comes first" (R29). Therefore GSOC is vital, according to this research, to guarantee that deviant behaviour will be thoroughly investigated. However, a further aspiration would be that duties towards accountability, and whistle-blowing in particular, are identified as personal responsibilities that should be encouraged as a habit of formal and informal operational-level Garda culture, and should not 'depend' on the subjectivities of interpretation of Gardaí, as may currently be the case. Nor should they solely be associated with the institutionally reactive preserves of oversight mechanisms. While recognising the perceived fear that Gardaí appear to have of GSOC and the potential inhibiting impact that this may have on the reporting of out of the ordinary behaviours, perhaps, more needs to be done to encourage the cultural validation of whistle-blowing in An Garda Síochána. 


\section{REFERENCES}

Alasuutari, P. (1995). Researching Culture: Qualitative Method and Cultural Studies, London: Sage.

An Garda Síochána (2009). Diversity Strategy. Dublin: An Garda Síochána.

An Garda Síochána (2009). National Model of Community Policing. Dublin: An Garda Síochána.

Bayley, D. H. (1998). Policing in America: assessments and prospects 3. retrieved $24^{\text {th }}$ May 2012, available at http://www.policefoundation.org/pdf/Bayley.pdf.

Brannick, T. and Coghlan, D. (2007) 'In Defense of Being "Native": The Case for Insider Academic Research', Organizational Research Methods, 10, 1, 59-74.

Brogden, M., \& Shearing, C.D. (1993). Policing for a New South Africa. New York: Routledge. Chan, J. (1997). Changing Police Culture: Policing a Multicultural Society. Cambridge: Cambridge University Press.

Chan, J. \& Dixon, D. (2007). The Politics of Police Reform: Ten Years after the Royal Commission into the New South Wales Police Service. Criminology and Criminal Justice, 7 (4), pp.443-468.

Conway, V. (2010). The Blue Wall of Silence: The Morris Tribunal and Police Accountability in Ireland. Dublin: Irish Academic Press.

Conway, V. \& Walsh, D. (2011).Current developments in Police Governance and Accountability in Ireland. Crime, Law and Social Change, 55 (2), pp. 241-257.

Crank, J.P. (1998). Understanding Police Culture. Cincinnati: Anderson Publishing.

Dannmiller, K., \& Jacobs, R. (1992). Changing the Way Organizations Change: a Revolution of Common Sense', Journal of Applied Behavioural Science, 28(4), pp.480-498.

Fitzgerald, T. P. (2008, March). The Morris Tribunal of Inquiry, Communiqué: Garda Management Journal. Dublin: An Garda Síochána.

Foster, J. (2003). 'Police Cultures', in T. Newburn (ed.) The Handbook of Policing, cullompton, Devon: Willan Publishing.

Graef, R. (1989). Talking Blues. London: Collins.

Holdaway, S. (1977). Changes in Urban Policing. British Journal of Sociology, 28 (2), pp.11937.

Janis, I.L. (1972). Victims of groupthink: a psychological analysis of conflict, choice and commitment, New York: Free Press.

Kouzes, J. and Posner, B. (2002) ( $3^{\text {rd }}$ ed.) The Leadership Challenge, San Francisco: Jossey Bass. 
Kvale, S. (1996) InterViews, London: Sage.

Lipsky, M. (1980). Street-level Bureaucracy: Dilemmas of the individual in public services. New York: Russell Sage Foundation.

Lindsay, P., \& Norman, D.A., (1977). Human Information Processing: An introduction to psychology. New York: Academic Press.

Loftus, B. (2012). Police Culture in a Changing World. Clarendon Series in Criminology, Oxford: Oxford University Press.

Loftus, B. (2010). Police Occupational Culture: Classic themes, altered times. Policing \& Society, 20 (1), pp. 1-20.

MacGreil, M. (1996). Prejudice in Ireland revisited, Kildare, Ireland: St. Patrick's College.

Manning, P. (2012).Trust and accountability in Ireland: The case of An Garda Síochána, Policing and Society: An International Journal of Research and Policy, Vol. 22 (3), pp. 346361.

McBarnett, D. (1981) Conviction, London: Macmillan.

McLaughlin, E. (2007). The New Police. London: Sage Publications.

Miller, S. (1999). Gender and Community Policing: Walking the Talk. Boston, MA: North Eastern University.

Morris, Justice, F. (2004 (1)). Report of the Tribunal of Inquiry set up pursuant to the Tribunal of Inquiry (Evidence) Acts 1921-2002 into certain Gardai in the Donegal Division: Report on explosive 'finds' in Donegal, term of reference (e). Dublin: Government Publications Sales Office.

Morris, Justice, F. (2005 (2)). Report of the Tribunal of Inquiry set up pursuant to the Tribunal of Inquiry (Evidence) Acts 1921-2002 into certain Gardai in the Donegal Division: Report on the investigation into the death of Richard Barron and extortion calls to Michael and Charlotte Peoples, term of reference ( $a$ ) and (b). Dublin: Government Publications Sales Office.

Morris, Justice, F. (2006 (5)). Report of the Tribunal of Inquiry set up pursuant to the Tribunal of Inquiry (Evidence) Acts 1921-2002 into certain Gardaí in the Donegal Division: Report on the arrest and detention of seven persons at Burnfoot, County Donegal on the 23rd of May and the investigation relating to same, term of reference (i). Dublin: Government Publications Sales Office.

Prenzler, T. (1997). Is there a Police Culture? Australian Journal of Public Administration, 56 (4), pp.47-56.

Reiner, R. (2000). The Politics of the Police. Oxford: Oxford University Press.

Reis, A.J. Jnr. (1972).The Police and the Public. New Haven: Yale University Press. 
Reuss-lanni, E. (1983). Two Cultures of Policing: Street Cops and Management Cops, London: Transactions Publishers.

Savage, S. (2007). Police Reform: Forces of Change. Oxford: Oxford University Press.

Senge, P. (2000). The Dance of Change, New York: Doubleday.

Shearing, C. \& Ericson, R. (1991). Culture as Figurative Action. British Journal of Sociology, 42 (4), pp.481-506.

Shiner, M. (2010) 'Post Lawrence Policing in England and Wales: Guilt, Innocence and the Defence of Organizational Ego', British Journal of Criminology, 50, 5, pp. 935-953.

Sklansky, D.A. (2006). Not Your Father's Police Department: Making Sense of the New Demographics of Law Enforcement. Journal of Criminal Law and Criminology, 96 (3), pp. 1209-1243.

Skolnick, J. (1969). The Politics of Protest. New York: Bantam.

Skolnick, J., \& Fyfe, J. (1993). Above the law: Police and the Excessive Use of Force. New York: Free Press.

Smith, D.J. and Gray, J. (1983). Police and People in London, The Police in Action, 4. London: Police Studies Institute.

Van Hulst, M. (2013) 'Storytelling at the Police Station: The Canteen Culture Revisited', British Journal of Criminology, Advance Access.

Van Maanen, J. and Schein, E.H. (1979). Toward a Theory of Organizational Socialization. Research in Organizational Behaviour, 1 (1), pp.209-64.

Vick, C. (1981). Police Pessimism, In D. Hope and N. Weiner (Eds.) Modern Policing. London: Croom Helm.

Waddington, P.A.J. (1999a). 'Police (canteen) Sub-culture: an appreciation', British Journal of Criminology, 39 (2) pp.287-309.

Walsh, D.P.J. (2009a). Tightening the Noose of Central Government Control over Policing in Ireland: Innovations in the Garda Síochána Act 2005. Northern Ireland Legal Quarterly, 60, pp. 163-180.

Weber, A. (1992). Social Psychology. New York: Harper Perennial.

Young, W.P. (2008). The Shack. Newbury Park, CA: Windblown Media.

Zhoa, J., Ne He, N., \& Lovrich, P. (1999). Value Change among Police Officers at a time of Organizational Reform: a follow-up study using Rokeach values. An International Journal of Police Strategies \& Management, 22 (2), pp.152-70. 